JSPS Grants-in-Aid for Scientific Research (S)

Understanding Persistent Deflation in Japan

Working Paper Series

No. 093

March 2017

\title{
The Optimum Quantity of Debt for Japan
}

\author{
Tomoyuki Nakajima \\ Shuhei Takahashi
}

\author{
UTokyo Price Project \\ 702 Faculty of Economics, The University of Tokyo, \\ 7-3-1 Hongo, Bunkyo-ku, Tokyo 113-0033, Japan \\ Tel: +81-3-5841-5595 \\ E-mail: watlab@e.u-tokyo.ac.jp \\ http://www.price.e.u-tokyo.ac.jp/english/
}




\title{
The Optimum Quantity of Debt for Japan*
}

\author{
Tomoyuki Nakajima ${ }^{\dagger}$ and Shuhei Takahashi ${ }^{\ddagger}$
}

February 15, 2017

\begin{abstract}
Japan's net government debt reached $130 \%$ of GDP in 2013. The present paper analyzes the welfare implications of the large debt for Japan. We use an Aiyagari (1994)-style heterogeneous-agent, incomplete-market model with idiosyncratic wage risk and endogenous labor supply. We find that under the utilitarian welfare measure, the optimal government debt for Japan is $-50 \%$ of GDP and the current level of debt incurs the welfare cost that is $0.22 \%$ of consumption. Decomposing the welfare cost by the Flodén (2001) method reveals substantial welfare effects arising from changes in the level, inequality, and uncertainty. The level and inequality costs are $0.38 \%$ and $0.52 \%$ respectively, whereas the uncertainty benefit is $0.68 \%$. Adjusting consumption taxes instead of the factor income taxes to balance the government budget substantially reduces the overall welfare cost.
\end{abstract}

Keywords: Government debt; welfare; incomplete markets; Japanese economy. JEL classification: E62, H63

${ }^{*}$ We thank Michio Suzuki, seminar participants at Kobe, Kyoto, and Okayama, and participants at 2015 Meiji University Conference, 2015 AEI Joint Workshop, 2015 DSGE Conference, 2015 International Conference on Computing in Economics and Finance, 2015 International Conference on Nonlinear Economic Dynamics, and 2015 Summer Workshop on Economic Theory for their helpful comments and suggestions. Nakajima gratefully acknowledges financial support from Grant-in-Aid for Scientific Research (S) 24223003 and (A)15H01939. Takahashi gratefully acknowledges financial support from Grant-in-Aid for Young Researchers (B) 26780119. Any remaining errors are our own.

${ }^{\dagger}$ Institute of Economic Research, Kyoto University, Yoshida-Honmachi, Sakyo-ku, Kyoto 606-8501, Japan, and Canon Institute for Global Studies.

†Institute of Economic Research, Kyoto University, Yoshida-Honmachi, Sakyo-ku, Kyoto 606-8501, Japan. 


\section{Introduction}

Japan's net government debt reached $130 \%$ of GDP in 2013 and the debt to GDP ratio is the highest among developed countries. A large number of papers, including Hoshi and Ito (2014), İmrohoroğlu, Kitao, and Yamada (2016), and Hansen and İmrohoroğlu (2016), analyze Japan's debt problem. ${ }^{1}$ However, the welfare effect of the large government debt has been less understood. Flodén (2001) finds that the optimal government debt for the United States is $150 \%$ of GDP. Is the optimal debt for Japan similar and hence should Japan accumulate more debt? Or does the current debt exceed the optimal level? How much is the welfare benefit of having the optimal level of debt instead of the current debt?

The present paper examines the welfare implications of government debt for Japan. We follow Aiyagari and McGrattan (1998) and Flodén (2001), which conduct a similar analysis for the United States, in using an Aiyagari (1994)-style heterogeneous-agent, incompletemarket model with idiosyncratic wage risk and endogenous labor supply. As discussed by Aiyagari and McGrattan (1998) and Flodén (2001), a change in government debt affects welfare through various channels in the model. In particular, Flodén (2001) decomposes the utilitarian welfare effect into effects on the level, inequality, and uncertainty. First, larger government debt crowds out of capital and larger required interest payments increase distortionary taxes, both of which worsen the level. ${ }^{2}$ Second, an increase in the interest rate is beneficial to wealth rich households, which worsens inequality. Third, an increase in the interest rate reduces the cost of savings and helps households to smooth consumption in the presence of idiosyncratic earnings risk. Further, an increase in labor income taxes lowers the after-tax wage rate, which reduces labor income risk. Both of these improve welfare by reducing uncertainty. ${ }^{3}$ The optimal quantity of debt depends on the relative strengthens of these effects.

\footnotetext{
${ }^{1}$ The following subsection reviews the related literature.

${ }^{2}$ Elmendorf and Mankiw (1999) list these costs as two readily quantifiable costs of government debt.

${ }^{3}$ Gottardi, Kajii, and Nakajima (2016) analyze the distribution and insurance effects of labor and capital income taxes in a two-period model with uninsurable idiosyncratic risk to labor and capital income.
} 
We calibrate the model to Japan's economy. One difficulty is the lack of an estimate for idiosyncratic wage risk. Idiosyncratic wage risk is typically estimated using panel data on individual wages, but such panel data is limited in Japan. We instead calibrate idiosyncratic wage risk to the standard deviation of log residual wages documented by Lise, Sudo, Suzuki, Yamada, and Yamada (2014). The result suggests that idiosyncratic wage risk in Japan is smaller than that in the United States, but is larger than that in Sweden estimated by Flodén and Linde (2001).

Using the calibrated model, we examine how a change in the amount of government debt affects the utilitarian welfare. We find that at our benchmark parameterization, the optimum quantity of government debt is negative for Japan and it is $-50 \%$ of GDP. Hence, the current level of $130 \%$ of GDP is too high in terms of welfare. The overall welfare cost of the current debt is $0.22 \%$ of consumption. However, the welfare benefit of improved uncertainty and the costs of worsened inequality and reduced the level are more substantial. Specifically, the uncertainty benefit is $0.68 \%$, whereas the inequality and level costs are $0.52 \%$ and $0.38 \%$ respectively.

The above result is derived by adjusting factor income taxes so that the government budget constraint is satisfied, as in Aiyagari and McGrattan (1998) and Flodén (2001). We find that when consumption taxes are adjusted, the optimal debt is $-40 \%$ of GDP. Hence, using consumption taxes does not rationalize the current amount of debt. However, the welfare cost of the current debt is substantially reduced. The current debt incurs a $0.14 \%$ cost in consumption in contrast to $0.22 \%$ in the benchmark case. The use of consumption taxes decreases the gain from reduced uncertainty and the costs from worsened level and inequality, but the reduction in the total welfare cost mainly arises form the decrease in the level cost.

The rest of the present paper is organized as follows. The following subsection reviews the literature on Japan's fiscal problem. Section 2 describes the model and Section 3 calibrates the model to Japan's economy. Section 4 presents results, whereas Section 5 concludes. 


\section{Related Literature}

Our paper contributes to the literature on Japan's fiscal problem by conducting welfare analyses. Previous works analyze various scenarios and options to stabilize debt in Japan, but there have been few welfare analyses. None of the existing work computes the optimal quantity of debt for Japan and evaluates the insurance and redistribution effects of government debt. We divide existing works into three groups based on their methodologies.

First, Broda and Weinstein (2005), Doi, Hoshi, and Okimoto (2011), and Hoshi and Ito (2014) directly work on the government budget constraint. Given the future paths of government expenditures and revenues as well as the interest and growth rates, the future path of government debt can be derived. The approach is simple and useful to analyze various scenarios, but it cannot give the welfare implications.

Second, several papers use a standard, representative-agent growth model to analyze Japan's fiscal problem. For example, İmrohoroğlu and Sudo (2011a) analyze how a rise in consumption tax rate from $5 \%$ to $15 \%$ affects Japan's primary surplus, whereas İmrohoroğlu and Sudo (2011b) analyze how TFP growth and fiscal adjustments affect the debt to GDP ratio in Japan. These papers do not conduct welfare analyses. Hansen and İmrohoroğlu (2016) compare welfare under a few levels of long-run debt, but they do not search for the optimal level of debt. In addition, using a representative-agent model, their study is silent about the insurance and redistribution effects of government debt. ${ }^{4}$

Third, recent papers use an overlapping generations model. Arai and Ueda (2013) use a simple overlapping generations model and analyze the level of primary deficits sustainable in the long run. İmrohoroğlu, Kitao, and Yamada (2016) construct a rich overlapping generations model describing Japan's pension system in detail. They use the model to project the path of government debt. Braun and Joines (2015) also develop a large-scale overlapping generations model that carefully describes the Japanese pension and health care systems.

\footnotetext{
${ }^{4}$ Hansen and İmrohoroğlu (2016) fully analyze the transition to a long-run level of debt, whereas as in Aiyagari and McGrattan (1998) and Flodén (2001), we focus on a stationary equilibrium.
} 
They analyze the future path of the debt to GDP ratio under several scenarios on fiscal adjustments. The paper does not include idiosyncratic earnings risk and hence it does not examine the insurance effect of government debt. Kitao (2015) constructs a rich life-cycle model that features uninsured idiosyncratic wage risk, intensive and extensive margin adjustments of labor supply, and pension, health care, and long-term care systems. The paper analyzes how the demographic transition in Japan affects the government budget, assuming that the debt to GDP ratio is fixed. Both Braun and Joines (2015) and Kitao (2015) examine the welfare effect for different cohorts, but do not analyze the redistribution consequences within cohorts.

\section{$2 \quad$ Model}

The model analyzed here is an Aiyagari (1994)-style model in which households use savings and labor supply to self-insure against idiosyncratic wage risk. In the same framework, Aiyagari and McGrattan (1998) and Flodén (2001) analyze the welfare implications of government debt for the United States. We extend their models by incorporating consumption taxes because a hike in consumption taxes is being discussed in Japan. ${ }^{5}$

\subsection{Firms}

A representative firm produces the single good by renting capital and labor from households. The production technology is represented by

$$
Y=K^{\theta}(z N)^{1-\theta}
$$

where $Y$ is output, $K$ is capital input, $N$ is labor input, $\theta \in(0,1)$ is the capital share, and $z$ is labor-augmenting productivity, which grows at a constant rate of $g$ or $z^{\prime}=(1+g) z$,

\footnotetext{
${ }^{5}$ In April 2014, the consumption tax rate rose to $8 \%$ from $5 \%$. The tax rate will rise to $10 \%$ in October 2019.
} 
where a next-period value is expressed with a prime hereinafter.

Given the rental rate of capital $r$ and the wage rate $w$, the firm maximizes its profit. The first-order conditions for profit maximization are

$$
r=\theta z^{1-\theta} K^{\theta-1} N^{1-\theta}-\delta
$$

and

$$
w=(1-\theta) z^{1-\theta} K^{\theta} N^{-\theta}
$$

where $\delta \in(0,1)$ is the capital depreciation rate. In the analysis below, we focus on an equilibrium where output grows at a constant rate of $g$. Hence, it is convenient to rewrite the above conditions as

$$
r=\frac{\theta}{\tilde{K}}-\delta
$$

and

$$
\tilde{w}=\frac{(1-\theta)}{N}
$$

where a variable with a tilde implies its ratio with respect to output (e.g., $\tilde{K}=K / Y$ ).

\subsection{Households}

There is a continuum of households of measure one. Households are endowed with one unit of time each period. Following Trabandt and Uhlig (2011), the momentary utility function is

$$
\begin{aligned}
u(c, h) & =\frac{1}{1-\mu}\left\{c^{1-\mu}\left[1-\kappa(1-\mu) h^{1+\frac{1}{\varphi}}\right]^{\mu}-1\right\} \text { if } \mu \neq 1, \mu>0 \\
& =\ln c-\kappa h^{1+\frac{1}{\varphi}} \text { if } \mu=1,
\end{aligned}
$$


where $c$ is consumption, $h \in[0,1]$ is hours worked, $\mu$ is the coefficient of relative risk aversion, $\kappa>0$ governs the disutility of labor, and $\varphi>0$ is the Frisch labor supply elasticity.

Households differ in their labor productivity. The specification of idiosyncratic productivity is taken from Flodén (2001) and Flodén and Linde (2001). Specifically, idiosyncratic productivity consists of two components. First, households differ in the permanent level of productivity $x$. This permanent component is drawn once at the beginning of period zero and it is fixed throughout. Second, households differ in the transitory level of productivity $e$. This transitory component is a finite-state Markov chain. Households' labor earnings are wxeh.

Asset markets are incomplete and only two risk-free assets, physical capital and government bonds, exist in the economy. These two assets are perfect substitutes for households and they earn the same interest rate $r$. Households use savings to self-insure against idiosyncratic wage risk. Accordingly, households differ in their transitory productivity $e$, permanent productivity $x$, and total asset holding $a$. There is a borrowing constraint: $a^{\prime} \geq 0$.

We describe the optimization problem of households in a stationary form. When $\mu=1$, which is our baseline specification, the problem is written as

$$
\begin{gathered}
V(\tilde{a}, e, x)=\max _{\left\{\tilde{c}, h, \tilde{a}^{\prime}\right\}}\left\{\ln \tilde{c}-\kappa h^{1+\frac{1}{\varphi}}+\beta E\left[V\left(\tilde{a}^{\prime}, e^{\prime}, x\right) \mid e\right]\right\} \\
\text { subject to }\left(1+\tau_{c}\right) \tilde{c}+(1+g) \tilde{a}^{\prime} \leq[1+(1-\tau) r] \tilde{a}+(1-\tau) \tilde{w} x e h+\tilde{T} \\
\tilde{c} \geq 0, h \in[0,1], \tilde{a}^{\prime} \geq 0,
\end{gathered}
$$

where $V(\tilde{a}, e, x)$ is the value function of households, $\beta \in(0,1)$ is the discount factor, and $E$ denotes conditional expectation. ${ }^{6}$ The second line is the budget constraint: $\tau_{c}$ is the consumption tax rate, $\tau$ is the common tax rate on capital and labor income, and $T$ is lump-sum transfers from the government to households (i.e., $\tilde{T}=T / Y$ ).

\footnotetext{
${ }^{6}$ In general, the future value is discounted by $\beta(1+g)^{1-\mu}$.
} 


\subsection{Government}

The government finances its consumption and lump-sum transfers to households through debt and taxes. The budget constraint is

$$
G+T+r B=B^{\prime}-B+\tau[w N+r(K+B)]+\tau_{c} C,
$$

where $G$ is government consumption, $B$ is government debt, and $C$ is aggregate consumption. The constraint in a stationary form can be obtained by dividing (8) by $Y$ :

$$
\tilde{G}+\tilde{T}+r \tilde{B}=(1+g) \tilde{B}^{\prime}-\tilde{B}+\tau[\tilde{w} N+r(\tilde{K}+\tilde{B})]+\tau_{c} \tilde{C} .
$$

In the baseline exercise, we vary $\tilde{B}$ and change $\tau$ to satisfy (9), while fixing $\left(\tilde{G}, \tilde{T}, \tau_{c}\right)$ at their benchmark value and changing $(r, \tilde{w}, N, \tilde{K}, \tilde{C})$ endogenously. This is the same exercise done by Aiyagari and McGrattan (1998) and Flodén (2001).

\subsection{Recursive Equilibrium}

Let $\Gamma(\tilde{a}, e, x)$ be a stationary distribution of households over wealth, transition productivity, and permanent productivity. Given the government policy $\left(\tilde{G}, \tilde{T}, \tilde{B}, \tau_{c}, \tau\right)$, a stationary competitive equilibrium $\left(\tilde{w}, r, V, \tilde{c}, \tilde{a}^{\prime}, h, \tilde{K}, N, \tilde{C}, \Gamma\right)$ satisfies the following conditions:

1. Households' optimization:

$V(\tilde{a}, e, x)$ satisfies $(7)$, while $\tilde{c}(\tilde{a}, e, x), \tilde{a}^{\prime}(\tilde{a}, e, x)$, and $h(\tilde{a}, e, x)$ are the associated policy functions.

2. Firms' optimization:

The representative firm chooses $\tilde{K}$ and $N$ to satisfy (4) and (5).

3. Labor market clearing:

$$
N=\int x h(\tilde{a}, e, x) d \Gamma
$$


4. Asset market clearing:

$$
\tilde{K}^{\prime}+\tilde{B}^{\prime}=\int \tilde{a}^{\prime}(\tilde{a}, e, x) d \Gamma
$$

5. Government budget constraint:

The government budget constraint holds, as in (9), with $\tilde{C}=\int \tilde{c}(\tilde{a}, e, x) d \Gamma$.

6. Stationary household distribution:

Household decisions and the transition probabilities of idiosyncratic productivity govern the evolution of the household distribution. Specifically, for all $D \subseteq Q$,

$\Gamma\left(D, e^{\prime}, x\right)=\int_{\left\{(\tilde{a}, e, x) \mid \tilde{a}^{\prime}(\tilde{a}, e, x) \in D\right\}} \pi_{e}\left(e^{\prime} \mid e\right) d \Gamma$,

where $\pi_{e}\left(e^{\prime} \mid e\right)$ is the transition probability from $e$ to $e^{\prime}$.

\section{Parameter Values}

We parameterize the model in a way similar to Nakajima and Takahashi (2016), which is based on the previous studies such as Hayashi and Prescott (2002), Sugo and Ueda (2008), and Nutahara (2015). Table 1 lists the parameter values. One period corresponds to one year. The growth rate of real GDP $g$ is $1.0 \%$. The capital depreciation rate $\delta$ is 0.06 and the capital share $\theta$ is 0.37 . The risk aversion parameter $\mu$ is 1.0 and the Frisch labor supply elasticity $\varphi$ is 1.0. The share of government expenditures in GDP $\tilde{G}$ is 0.154 . The benchmark debt to GDP ratio $\tilde{B}$ is 1.1 . We set the share of government transfers $\tilde{T}$ to 0.126 , which is the benchmark result in Nakajima and Takahashi (2016). The consumption tax rate $\tau_{c}$ is $5 \%$.

For idiosyncratic productivity, as in Flodén and Linde (2001) and Flodén and Linde (2001), we assume that $\ln x \sim N\left(0, \sigma_{x}^{2}\right)$ and that the transitory component is derived from $\ln e^{\prime}=\rho \ln e+\varepsilon^{\prime}$, where $\varepsilon^{\prime}$ is independently distributed as $N\left(0, \sigma_{\varepsilon}^{2}\right)$, using Tauchen (1986)'s 


\begin{tabular}{ccc}
\hline \hline Symbol & Meaning & Value \\
\hline$g$ & Growth rate & 0.01 \\
$\delta$ & Capital depreciation rate & 0.06 \\
$\theta$ & Capital share & 0.37 \\
$\mu$ & Relative risk aversion & 1.0 \\
$\varphi$ & Frisch labor supply elasticity & 1.0 \\
$\tilde{G}$ & Government consumption-output ratio & 0.154 \\
$\tilde{B}$ & Debt-output ratio & 1.1 \\
$\tilde{T}$ & Transfer-output ratio & 0.126 \\
$\tau_{c}$ & Consumption tax rate & 0.05 \\
$\rho$ & Persistence of idiosyncratic productivity & 0.90 \\
$\sigma_{\varepsilon}$ & Volatility of idiosyncratic productivity shocks & 0.1754 \\
$\sigma_{x}$ & Dispersion of permanent productivity & 0.2530 \\
$\kappa$ & Disutility of labor & 6.75 \\
$\beta$ & Discount factor & 0.9872 \\
\hline \hline
\end{tabular}

Table 1: Parameter values.

method. ${ }^{7}$ These parameters for idiosyncratic productivity are typically estimated using panel data on individual wages. However, since such panel data is limited in Japan, we choose the parameter values by targeting the cross-sectional variance of wages. ${ }^{8}$ In particular, we use the results in Lise, Sudo, Suzuki, Yamada, and Yamada (2014). First, the variance of $\log$ of residual wages for men is 0.163 for the period between 1995 and 2008 . We assume that this residual wage dispersion is generated by the transitory component of idiosyncratic productivity. Hence, we set $\sigma_{\varepsilon}^{2} /\left(1-\rho^{2}\right)=0.162$. The lack of panel data implies a lack of separate estimates for $\rho$ and $\sigma_{\varepsilon}$. Existing analyses for other countries find that the transitory component is quite persistent. For example, Flodén and Linde (2001) find that $\rho=0.914$ for the United States and $\rho=0.814$ for Sweden, whereas Alonso-Ortiz and Rogerson (2010) use $\rho=0.94$ for the United States based on the estimates by various studies. Hence, we set $\rho=0.90$ as the benchmark for Japan. The corresponding $\sigma_{\varepsilon}$ is 0.1754 . Second, the variance of $\log$ raw wages for men is 0.226 . We then choose $\sigma_{x}$ so that the overall wage dispersions match between the model and actual data. In other words, $\sigma_{\varepsilon}^{2} /\left(1-\rho^{2}\right)+\sigma_{x}^{2}=0.226$ or

\footnotetext{
${ }^{7}$ The transitory productivity process is approximated with a 17-state Markov chain, whereas the permanent component is approximated with 5 states.

${ }^{8}$ We thank Michio Suzuki for the suggesiton.
} 
$\sigma_{x}=0.2530$.

The parameter values on idiosyncratic productivity in Japan lie between the estimates for the United States and Sweden by Flodén and Linde (2001). The standard deviation of the permanent component $\sigma_{x}$ is 0.2530 in Japan, 0.3428 in the United States, and 0.2161 in Sweden. In contrast, the wage dispersion generated by the transitory component $\sigma_{\varepsilon}^{2} /\left(1-\rho^{2}\right)$ is 0.162 in Japan, 0.2588 in the United States, and 0.0966 in Sweden. Hence, both the permanent and transitory components in Japan are between those in the United States and Sweden.

Lastly, we set the discount factor $\beta$ and the disutility of labor $\kappa$ so that the after-tax return on savings is $2.06 \%$ and the total hours worked is 0.212 .

\section{Results}

Our welfare measure is utilitarian, as in the most of related studies, such as Aiyagari and McGrattan (1998) and Flodén (2001). The measure can also be seen as the expected utility of a household before drawing the initial state. In our benchmark case with a log consumption utility function, the welfare under a certain level of government debt is computed by

$$
U=\frac{\ln Y_{0}}{1-\beta}+\frac{\beta \ln (1+g)}{(1-\beta)^{2}}+\iint V(\tilde{a}, e, x) d \Gamma
$$

The first term adjusts the level of consumption and $Y_{0}$ is the output level at the initial date whose productivity is normalized to 1.0. This part is affected by the level of government debt through its effect on the capital-output ratio and aggregate labor input (i.e., $Y_{0}=\tilde{K}^{\theta} N^{1-\theta}$ ). The second term adjusts the exogenous growth and it is invariant to a change in government debt. The third term is the utilitarian welfare computed above for the stationary equilibrium and it depends on the level of debt.

Next, we evaluate the welfare effect of changing government debt from the optimal level. In particular, the welfare gain shows how much consumption at the optimal equilibrium must 
increase at all states and dates in order to achieve the utilitarian welfare under a certain level of debt. Hence, the gain is the largest and zero at the optimal level of debt. In our benchmark case with a log consumption utility function, the welfare gain $\omega_{U}$ is computed by

$$
\omega_{U}=\exp \left[\beta\left(U-U^{*}\right)\right]-1
$$

where $U^{*}$ is the utilitarian welfare $(10)$ at the optimal level of government $\operatorname{debt}\left(\tilde{B}=\tilde{B}^{*}\right)$.

As discussed by Aiyagari and McGrattan (1998) and Flodén (2001), a change in government debt affects the utilitarian welfare through several channels. In order to quantify each effect, we follow the method of Flodén (2001) and decompose the utilitarian welfare gain $\omega_{U}$ in (11) into gains related to changes in the level, uncertainty, and inequality:

$$
\omega_{U}=\left(1+\omega_{\text {lev }}\right)\left(1+\omega_{\text {unc }}\right)\left(1+\omega_{\text {ine }}\right)-1
$$

The level gain $\omega_{l e v}$ is the gain arising from a change in the level of aggregate consumption (a change in aggregate leisure is compensated). The further decomposition into the uncertainty gain $\omega_{\text {unc }}$ and the inequality gain $\omega_{\text {ine }}$ is done as follows. For each state, we compute certainty-equivalent consumption and leisure. ${ }^{9}$ The uncertainty gain $\omega_{\text {unc }}$ is the gain in the uncertainty cost, which is computed by the welfare difference between having the average consumption and leisure and having the average certainty-equivalent consumption and leisure. In contrast, the inequality gain $\omega_{\text {ine }}$ is the difference in the cost of inequality, which is computed by the difference between the welfare of having the average certainty-equivalent consumption and leisure and the average welfare of having certainty-equivalent consumption and leisure.

The results are shown in Figure 1 and summarized in Table 2. At the benchmark parame-

\footnotetext{
${ }^{9}$ The pair of certainty-equivalent consumption and leisure is not unique. The result reported here is based on the assumption that certainty-equivalent leisure is the current leisure choice, following Flodén (2001). The result does not change substantially even when we set certainty-equivalent leisure to the economy average leisure.
} 

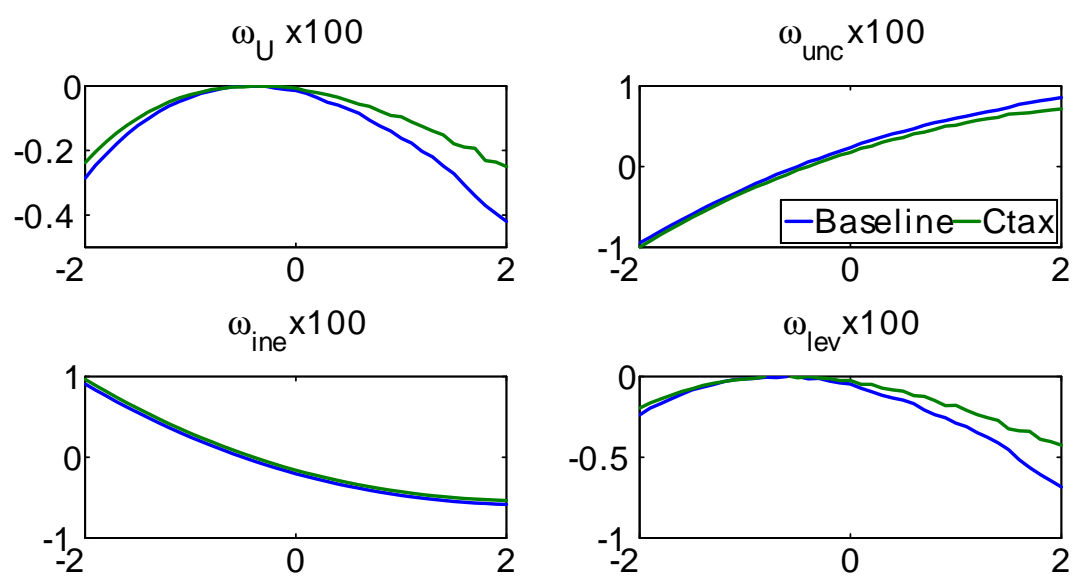

Figure 1: Welfare. Horizontal axis: debt to GDP ratio.

\begin{tabular}{cccccc}
\hline \hline & & Baseline & Ctax & $\rho=0.80$ & $\rho=0.97$ \\
\hline$\tilde{B}^{*}$ & & -0.5 & -0.4 & -0.7 & -1.2 \\
\hline$\tilde{B}=1.3$ & $\omega_{U} \times 100$ & -0.22 & -0.14 & -0.34 & -0.34 \\
& $\omega_{\text {unc }} \times 100$ & 0.68 & 0.59 & 0.68 & 0.98 \\
& $\omega_{\text {ine }} \times 100$ & -0.52 & -0.48 & -0.56 & -0.73 \\
& $\omega_{\text {lev }} \times 100$ & -0.38 & -0.26 & -0.45 & -0.57 \\
\hline$\tilde{B}=2.0$ & $\omega_{U} \times 100$ & -0.42 & -0.25 & -0.56 & -0.52 \\
& $\omega_{\text {unc }} \times 100$ & 0.85 & 0.71 & 0.74 & 1.16 \\
& $\omega_{\text {ine }} \times 100$ & -0.58 & -0.53 & -0.56 & -0.82 \\
& $\omega_{\text {lev }} \times 100$ & -0.68 & -0.42 & -0.74 & -0.85 \\
\hline \hline
\end{tabular}

Table 2: Summary of the welfare results.

terization, the optimum quantity of government debt is negative for Japan and it is $-50 \%$ of GDP. Hence, the current level of $130 \%$ of GDP is too high in terms of welfare. However, the overall welfare is relatively insensitive to the debt to GDP ratio, as shown in the upper-left panel of Figure 1. The current level of debt incurs a cost of $0.22 \%$ of consumption. Even when debt reaches $200 \%$ of GDP, the welfare cost is $0.42 \%$.

Next, we look at how government debt affects the level, uncertainty and inequality gains. As shown in the rest of the panels of Figure 1, a change in government debt moves the three gains differently. The inequality gain worsens monotonically with the debt to GDP ratio, while the uncertainty gain improves. The level gain first improves and then deteriorates. 


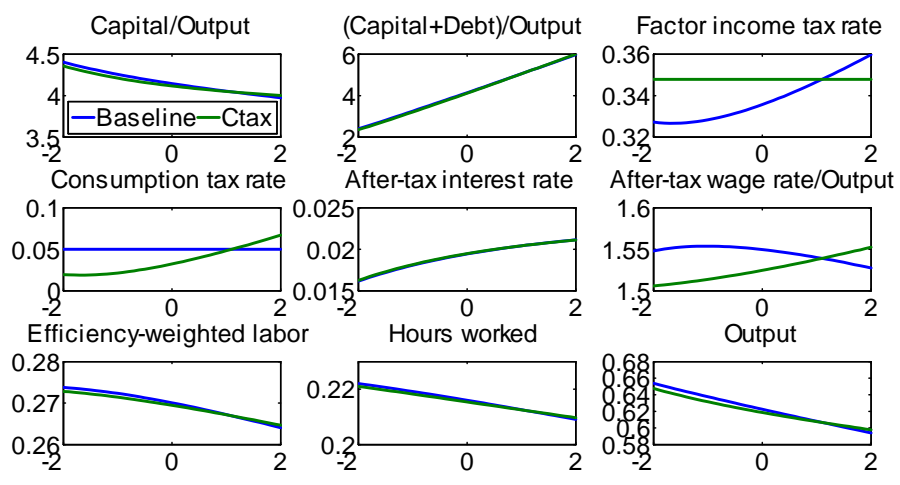

Figure 2: Aggregate variables. Horizontal axis: debt to GDP ratio.

Further, while the overall cost is mild, the magnitudes of the three gains are sizable. The current debt generates a $0.38 \%$ level cost and a $0.52 \%$ inequality cost, whereas the uncertainty gain is $0.68 \%$.

In order to understand these welfare results, we examine how aggregate variables change as the debt to GDP ratio changes (Figure 2). The after-tax return on savings rises, while the capital to GDP ratio decreases. The total asset in the economy, the sum of capital and debt relative to output, increases. Aggregate hours worked and efficiency-weighted labor both decrease, while the before-tax wage rate rises (not shown in the figure). Further, when debt is low, an increase in debt leads to an increase in the tax base, and this outweighs an increase in the interest payments (or outweighs the decrease in the interest receipts). Thus, the tax rate decreases slightly before rising. Hence, the after-tax wage rate initially rises before falling.

These movements of aggregate variables explain the welfare effects of government debt as follows. Increasing debt improves uncertainty by making households hold larger wealth with the increased interest rate and hence making them better insured against idiosyncratic risk. In addition, the after-tax wage rate eventually decreases, which also reduces earnings risk. Second, the combination of the higher return on savings and the lower wage rate is bad for small-wealth households and good for large-wealth households. Hence, an increase 
in debt worsens inequality. The level gain is not monotone. When debt is sufficiently low, capital overaccumulation is severe and low-productivity households work long inefficiently. An increase in debt eliminates these problems and the level gain is initially positive.

So far, we have adjusted factor income taxes so that the government budget constraint is satisfied, as in Aiyagari and McGrattan (1998) and Flodén (2001). Next, we instead adjust consumption taxes, fixing the factor income tax rate at the benchmark rate. One motivation for this exercise is that in a representative-agent model (Hansen and İmrohoroğlu (2016)) and an overlapping generations model (Kitao (2015)), consumption taxes are found to be less distortionary than labor income taxes to address Japan's fiscal problem. We find that the optimal debt when consumption taxes are adjusted is $-40 \%$ of GDP. Hence, using consumption taxes does not rationalize the current amount of debt. However, the welfare cost of government debt is substantially reduced. Specifically, the current debt incurs a $0.14 \%$ cost in consumption in contrast to $0.22 \%$ in the benchmark scenario. The uncertainty gain is smaller compared to the benchmark case because as shown in Figure 2, the after-tax wage rate (relative to output) increases, which magnifies earnings risk. In contrast, the inequality cost is smaller because the rise in the wage rate helps poor households whose income mainly comes from labor earnings. Lastly, as is consistent with the previous studies, consumption taxes are less distortionary than labor income taxes and the level cost decreases relative to the benchmark case. Indeed, the level cost decreases from $0.38 \%$ to $0.26 \%$ and the reduction in the level cost is most responsible for the decrease in the total welfare cost.

Lastly, we examine whether the welfare implications of government debt are sensitive to the process for idiosyncratic productivity. For that, we adjust $\rho$ and $\sigma_{\varepsilon}$, maintaining $\sigma_{\varepsilon}^{2} /\left(1-\rho^{2}\right)=0.162$. We consider two cases. The first case is a lower persistence $(\rho=0.80$ and $\left.\sigma_{\varepsilon}=0.2415\right)$ than the benchmark case, whereas the second case assumes a higher persistence $\left(\rho=0.97\right.$ and $\left.\sigma_{\varepsilon}=0.0978\right)$. In both cases, we adjust $\beta$ and $\kappa$ in order to attain the after-tax return on savings and total hours worked same as those in the baseline case.

As shown in Table 2, the main results under the benchmark calibration are robust to 
the change in idiosyncratic wage risk. The optimal debt is negative for Japan and therefore the current debt is too large in terms of welfare. The current debt generates a substantial welfare gain by reducing uncertainty, but produces a significant cost by worsening the level and inequality. These factors offset with one another and therefore the overall welfare effect is smaller than each of the three effects.

\section{Conclusion}

Japan's net government debt reached $130 \%$ of GDP in 2013. We have analyzed the welfare implications of Japan's large debt. We have found that the current level of debt exceeds the optimal level. The overall welfare cost is mild, but the welfare costs of the worsened level and inequality and the welfare benefit of reduced uncertainty are more substantial.

\section{References}

Aiyagari, S. R. (1994): "Uninsured Idiosyncratic Risk and Aggregate Saving," Quarterly Journal of Economics, 109(3), 659-684.

Aiyagari, S. R., and E. R. McGrattan (1998): "The Optimum Quantity of Debt," Journal of Monetary Economics, 42(3), 447-469.

Alonso-Ortiz, J., and R. Rogerson (2010): "Taxes, Transfers and Employment in an Incomplete Markets Model," Journal of Monetary Economics, 57(8), 949-958.

Arai, R., And J. Ueda (2013): "A Numerical Evaluation of the Sustainable Size of the Primary Deficit in Japan," Journal of Japanese International Economies, 30, 59-75.

Braun, A., And D. H. Joines (2015): "The Implications of a Graying Japan for Government Policy," Journal of Economic Dynamics and Control, 57, 1-23. 
Broda, C., and D. E. Weinstein (2005): "Happy News from the Dismal Science: Reassessing Japanese Fiscal Policy and Sustainability," in Reviving Japan's Economy, ed. by T. Ito, H. Patrick, and D. E. Weinstein, pp. 40-78. MIT Press.

Doi, T., T. Hoshi, and T. Oкiмото (2011): "Japanese Government Debt and Sustainability of Fiscal Policy," Journal of the Japanese and International Economics, 25(4), $414-433$.

Elmendorf, D. W., and G. N. Mankiw (1999): "Government Debt," in Handbook of Macroeconomics, ed. by J. B. Taylor, and M. Woodford, vol. 1, pp. 1615-1669.

Flodén, M. (2001): "The Effectiveness of Government Debt and Transfers as Insurance," Journal of Monetary Economics, 48(1), 81-108.

Flodén, M., And J. Linde (2001): "Idiosyncratic Risk in the United States and Sweden," Review of Economic Dynamics, 4(2), 406-437.

Gottardi, P., A. KajiI, and T. Nakajima (2016): "Constrained Inefficiency and Optimal Taxation with Uninsurable Risks," Journal of Public Economic Theory, 18(1), 1-28.

Hansen, G. D., and S. İmrohoroğLu (2016): "Fiscal Reform and Government Debt in Japan: A Neoclassical Perspective," Review of Economic Dynamics, 21, 201-224.

Hayashi, F., and E. C. Prescott (2002): "The 1990s in Japan: A Lost Decade," Review of Economic Dynamics, 5(1), 206-235.

Hoshi, T., And T. Ito (2014): "Defying Gravity: Can Japanese Sovereign Debt Continue to Increase without a Crisis?," Economic Policy, 29, 5-44.

İmrohoroğLu, S., S. Kitao, and T. Yamada (2016): "Achieving Fiscal Balance in Japan,” International Economic Review, 57(1), 117-154. 
İmrohoroğLu, S., and N. Sudo (2011a): "Productivity and Fiscal Policy in Japan: ShortTerm Forecasts from the Standard Growth Model," Monetary and Economic Studies, November.

— (2011b): "Will a Growth Miracle Reduce Debt in Japan?," IMES Discussion Paper Series, E-1.

Kitao, S. (2015): "Fiscal Cost of Demographic Transition in Japan," Journal of Economic Dynamics and Control, 54, 37-58.

Lise, J., N. Sudo, M. Suzuki, K. Yamada, and T. Yamada (2014): "Wage, Income and Consumption Inequality in Japan, 1981-2008: From Boom to Lost Decades," Review of Economic Dynamics, 17(4), 582-612.

Nakajima, T., and S. Takahashi (2016): "The Effectiveness of Consumption Taxes and Transfers as Insurance against Idiosyncratic Risk," KIER Discussion Paper Series.

Nutahara, K. (2015): "Laffer Curves in Japan," Journal of the Japanese and International Economies, 36, 56-72.

Sugo, T., And K. Ueda (2008): "Estimating a Dynamic Stochastic General Equilibrium Model for Japan," Journal of the Japanese and International Economics, 22(4), 476-502.

Tauchen, G. (1986): "Finite State Markov-Chain Approximations to Univariate and Vector Autoregressions," Economics Letters, 20(2), 177-181.

Trabandt, M., and H. Uhlig (2011): "The Laffer Curve Revisited," Journal of Monetary Economics, 58(4), 305-327. 